\title{
Improving food security in Nigeria through livestock innovation
}

\author{
Nina Gavrilova ${ }^{1, *}$ \\ ${ }^{1}$ Institute for African Studies of the Russian Academy of Sciences, Centre for Transition Economy \\ Studies, 123001, Moscow, Russia
}

\begin{abstract}
The challenge of ensuring food security, which concerns not only the availability of food products but also their nutritional quality, is particularly important for modern Nigeria. The diet of the population lacks sufficient animal protein, which entails many health problems. Nigeria's livestock sector, despite its considerable size, is not able to satisfy the demand of the rapidly growing population for animal protein. The steady development of animal husbandry in Nigeria is hindered by the escalating conflict between farmers and pastoralists, which causes loss of life, destruction of crops and livestock. The Nigerian authorities have made repeated attempts to find a solution to resolve the conflict, one of them being the decision to establish livestock ranches that would limit the grazing area and thereby eliminate the main cause of the tensions constant migrations of livestock, but to no avail. Modern laws do not take into account many of the nuances that make attempts to organize livestock farming in fenced areas unfeasible. However, keeping farm animals on ranches is an innovative way to develop livestock in Nigeria. The author believes that Nigerian laws regulating the livestock sector require significant modification, where special attention should be paid to innovative components.
\end{abstract}

\section{Introduction}

Prior to independence, agriculture was the leading sector of the Nigerian economy. Colonial Nigeria was able to fully provide its population with food and exported a significant volume of agricultural products. After the country became independent, the dynamics of its economic development became determined by the accelerated industrial development of oil and gas resources, which were discovered in the late 1960s [1]. At the same time, there was a decline in the production of certain types of agricultural products, which in the 1970s led to a change in the country's place in the system of global division of labor: Nigeria lost the role of a supplier of some types of agricultural raw materials to the world market. Since that time, the country has firmly taken a place in the top ten world oil exporters, while gradually losing advanced agriculture and the ability to provide its population with food [2].

\footnotetext{
*Corresponding author: ninagavrilova1976@gmail.com
} 
However, agriculture has not lost its relevance to Nigeria. Although the main industry that generates the highest export earnings is the oil and gas sector, about $70 \%$ of the working population is employed in agriculture [3]. In addition, agricultural products are the second largest source of foreign exchange earnings after crude oil; in 2001-2017, the average annual value of agricultural exports amounted to $3.4 \%$ of the total exports (approximately $\$ 3$ billion). Of great importance for the economy is the export of animal skins (of cattle, sheep and goats). The problem of export diversification through an increase in the share of agricultural production has been facing Nigeria for many decades, but so far there have been no major shifts for the better [4].

Among the greatest challenges of providing the population of Nigeria with food remains not just the problem of food shortages, but also the problem of an unbalanced diet, which causes many health problems. Adding animal products to the diet would help compensate for the lack of animal proteins and even out the protein and energy balance, the violation of which leads to the loss of immunity, growth retardation and the development of anemia and other diseases in children $[5,6]$.

The animal husbandry sector in Nigeria in its current state is unable to ensure the selfsufficiency of the population in animal products. The country has significant livestock resources, including cattle, sheep, goats, pigs, poultry, as well as coastlines and reservoirs for fish farming and fishing, but they are not sufficient to meet the demand of the population. Researchers conclude that the growth rate of the Nigerian population is faster than that of the population of farm animals [7, p. 54], and despite the positive dynamics in meat and fish production, the external dependence of Nigeria on imports, whose share in livestock production is about $20 \%$, has not yet been overcome. Besides, the country is the most densely populated in Africa (195.8 million people in 2018) [3], the population growth in 2018 stood at $2.6 \%$, and it is expected that by 2050 the number of Nigerians will have almost doubled and reached 402 million people [8]. Correspondingly, the demand for food products of animal origin will increase even further. Under the circumstances, it is extremely important to pay attention to the problems that impede the full-fledged development of animal husbandry, since its accelerated development is the most important direction in strengthening the country's food security, improving the diet of the population and modernizing the agricultural sector of the economy. Particular attention should be paid to the main obstacle to the development of animal husbandry - the conflicts between farmers and pastoralists, which not only cause casualties among people and animals, interrupt the peaceful life of the population, but also undermine the country's food security.

\section{Materials and Methods}

The work uses statistical data on the livestock sector presented mainly in databases of the Food and Agriculture Organization of the United Nations (FAO). The author also relies on related research by Russian and foreign scholars, reports and documents of the FAO, the World Bank, International Crisis Group, the Organisation for Economic Co-operation and Development (OECD), etc.

In order to analyze the attempts to resolve conflicts between farmers and pastoralists, the paper reviews legislative acts concerning animal husbandry, including the National Grazing Reserve, Open Grazing Prohibition and Establishment of Ranches Law and the 10year National Livestock Transformation Plan 2018-2027. In the study, the author applies empirical (collection of statistical information), theoretical (analysis and synthesis of statistical information, its classification) and quantitative (statistical and bibliometric) methods. 


\section{The current state of the livestock sector}

The diet of Nigerians is dominated by plant foods that do not contain all the substances necessary for good health. The consumption of animal protein in the country averages $10 \mathrm{~g}$ per capita per day, while the recommended daily norm is 50-65 g/cap [3]. Proteins are the most important elements in the diet of the population, especially children, pregnant women and the elderly. Their deficit entails many health problems: $11 \%$ of Nigerian children suffer from malnutrition, $43.6 \%$ of children are stunted; $49.8 \%$ of women of reproductive age between 15 and 49 years old suffer from anemia [3]. The main source of animal protein is meat, but in terms of its consumption Nigeria steadily occupies one of the lowest places in the world: in the ranking of the 43 largest countries ordered by the amount of meat consumed per capita, Nigeria is in the $39^{\text {th }}$ place, only slightly ahead of India, Bangladesh and Ethiopia [9, p. 284]. People who lack animal protein in their diet have weak immunity and are poorly protected from infections.

OECD specialists, based on current trends, predict a decrease in meat consumption in Nigeria from $5.3 \mathrm{~kg} / \mathrm{cap}$ on average for $2016-2018$ down to $4.6 \mathrm{~kg} / \mathrm{cap}$ per year by 2028 , which will further exacerbate the problem of the deficit of animal protein in the diet. To illustrate the scale of livestock production, Table 1 provides a calculation of the share of Nigeria's herds in West Africa, Africa, and the world.

Table 1. Livestock stocks, 2018 [3].

\begin{tabular}{|c|c|c|c|c|c|c|c|}
\hline \multirow{2}{*}{$\begin{array}{c}\text { Type of } \\
\text { animals }\end{array}$} & \multicolumn{4}{|c|}{ Livestock, million animals } & \multicolumn{3}{c|}{ Share of Nigeria in, \% } \\
\cline { 2 - 8 } & Nigeria & West Africa & Africa & World & $\begin{array}{c}\text { West } \\
\text { Africa }\end{array}$ & Africa & World \\
\hline Cattle & 21,4 & 78,8 & 355,7 & 1490 & 27,2 & 6,0 & 1,4 \\
\hline Sheep & 43,0 & 115,3 & 384,0 & 1210 & 37,3 & 11,2 & 3,6 \\
\hline Goats & 79,4 & 170,9 & 438,1 & 1046 & 46,5 & 18,1 & 7,6 \\
\hline Pigs & 7,5 & 14,3 & 40,5 & 978 & 52,5 & 18,5 & 0,8 \\
\hline Poultry & 139,4 & 523,7 & 1882,4 & 23707 & 26,6 & 7,4 & 0,6 \\
\hline
\end{tabular}

Over the nearly 60-year period of independent development, the number of domestic animals in Nigeria has undergone significant changes: the number of poultry (chickens) has grown 4 times, goats -188 times, pigs -12 , sheep -41 , cattle -3.5 times [3]. It should be noted that Nigeria has the largest livestock of sheep (37.3\% of the total for the region), goats $(46,5 \%)$ and pigs $(52.5 \%)$ in West Africa. Nigeria also possesses significant livestock stocks of cattle. 


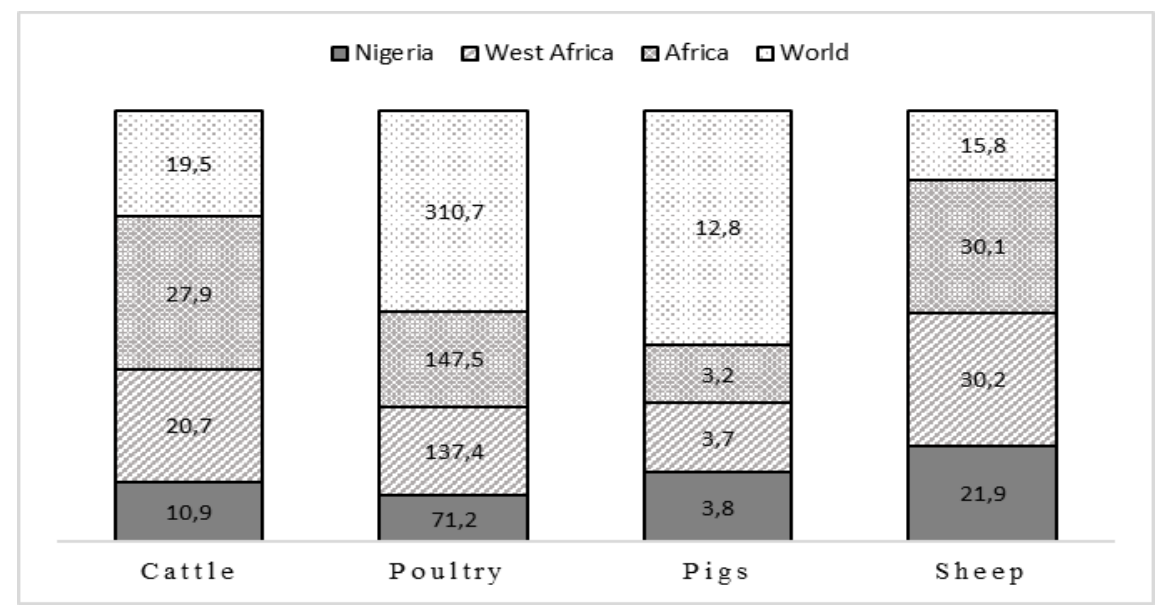

Fig. 1. Livestock heads per 100 people, 2018 [Ошибка! Источник ссылки не найден.].

However, this does not solve the problem of low animal protein intake, as any growth in production is offset by a larger growth in population. Fig. 1 demonstrates how the number of farm animals in Nigeria, West Africa, Africa as a whole, and in the world differs per 100 people.

The state of animal husbandry in Nigeria can be considered unsatisfactory because it cannot ensure the country's self-sufficiency in corresponding products; therefore, significant amounts of foreign currency are spent on the purchase of the lacking food, mainly beef, fish, and processed dairy products.

\section{The current state of the livestock sector}

OECD experts predict that meat consumption in Africa will increase by only $25 \%$, despite the anticipated population increase of $30 \%$ over the next decade [9, p. 31]. There exist several explanations of this. The production of livestock products in Nigeria is fraught with many problems that impede the provision of optimal amounts of food of animal origin. Livestock industry is at great risk: in recent decades, epidemics have repeatedly occurred among animals and poultry, the number of which has declined sharply. Viruses of highly pathogenic bird flu, horse plague, African swine fever, etc., the spread of the tsetse fly and the low level of veterinary services for animals not only make it difficult to maintain the livestock, but also reduce the export of livestock products to neighboring countries.

The sustainable development of agriculture, including animal husbandry, is also hindered by the emergence of conflict situations. Pastoralists roam with their herds throughout Nigeria for most of the year; stationary housing of animals is rarely practiced.

The alteration of traditional pastoralists' routes in the early $20^{\text {th }}$ century increased the number of disputes over crop damage because of uncontrolled grazing, water pollution, and cattle theft [10]. Due to the lack of mutually acceptable mechanisms for resolving them, disputes are becoming increasingly violent. Tensions between farmers and pastoralists have intensified markedly in the last decade - especially in central and southern states; clashes occurred in at least 22 of the 36 states of the country, and more than 3800 people were injured over the period of 18 months. Incidents with pastoralists accounted for $44 \%$ of all deaths in the country in 2016 [11]. Tens of thousands of people left their homes, and their property, land and livestock were destroyed. The damage has amounted to billions of naira, both farmers and herders have suffered, economy has been hurt and food security has declined. 
Herders own about $90 \%$ of the national herd, which is estimated to comprise about 19.5 million heads of cattle, 72 million goats and 41 million sheep [3, 11], so conflicts between farmers and pastoralists require immediate resolution.

\section{The government's attempts to increase livestock breeding efficiency}

Many researchers consider factors that impede the development of animal husbandry, such as inadequate funding, the high cost of feed for animals, animal diseases, lack of infrastructure, deficit of government incentives, transportation and other factors that hamper the production of animals [7, 11, 13, etc.]. However, according to our opinion, more attention should be paid to changing the very method of animal husbandry.

In the history of Nigeria, there have already been attempts to force nomadic herds into fenced areas. Nigerian authorities have made numerous attempts to resolve conflicts between farmers and pastoralists. For instance, back in 1965, the government allocated large tracts of land in many regions for grazing, which were to be used exclusively for raising livestock [11]. However, during the civil war of 1967-1970, these lands became federal property. The ranches were abandoned over a few years and are currently in decrepit condition.

In 2016, the Parliament drafted the National Grazing Reserve bill, aimed at resolving conflicts between pastoralists and farmers, but it was not adopted as it contradicted provisions of the 1978 Land Use Act, which empowered state governors to regulate tenure, acquisition and management of Nigeria's land. State governments and their representatives in parliament opposed all attempts to create pasture reserves in their regions, believing that it is more profitable to use land not for the development of cattle breeding, but for other industries. Consequently, no relevant amendments to the Land Use Act were made.

To resolve conflicts between farmers and pastoralists, some state governments adopted extreme measures. For example, in 2017, Benue State passed the Open Grazing Prohibition and Establishment of Ranches Law [14], which led to heated discussions: some were satisfied with its adoption, while others fiercely opposed it. Among those who supported the adoption of the law were farmers, who were content that livestock would no longer spoil their produce. The opposite side were pastoralists, who would be left without pasture.

Similar laws prohibiting uncontrolled cattle grazing have been passed in the states of Ekiti, Edo and Taraba, although the latter has not impose sanctions for its violation. The bans on grazing were introduced in 2016-2017, but no land was allocated for pastoralists. Only in 2018 did the government approve the 10-year National Livestock Transformation Plan 2018-2027, which provided for the creation of 94 ranches in 10 states of the federation. However, some state governments rejected the proposal due to the lack of land for such projects. Currently, the organization of ranches is scheduled in the states of Adamawa, Benue, Kaduna, Nassarawa, Plateau, Taraba and Zamfara.

Thus, successive governments - from the First Republic to the Fourth one - could not revive abandoned ranches that could bring income to the country, create jobs and help achieve food security. If we sum up the problems that led to the destruction of ranches, they include the incongruence between modern realities and the outdated land law; the limited use of specialized livestock breeds; the lack of quality feed; the lack of qualified manpower to care for animals and manage farms. 


\section{Conclusion}

Most Nigerians lack protein of animal origin, which causes negative health effects. Increasing the volume of animal products in the diet will help overcome the lack of animal protein, improve the quality of the diet and positively affect the food security of Nigeria. To ensure these positive developments, it is necessary to overcome certain obstacles in the production of livestock products. The main obstacle is the escalating conflicts between pastoralists and farmers. In order to extinguish these conflicts, a detailed development plan should be developed for the establishment of ranches - limited, fenced areas for cattle breeding. The main and constant problem of nomadic animal husbandry is the search for food supply and water. The sedentary way of producing livestock products - the creation of ranches and other livestock complexes - is aimed at developing a high-quality and effective feeding system that provides meat and dairy products of a larger volume and higher quality. Animals do not spend energy on constant migrations, therefore, the rate of production increases dramatically; animals can also obtain veterinary care. Livestock complexes must be located in areas free of dangerous parasites, for example, tsetse flies.

The 10-year National Livestock Transformation Plan 2018-2027, developed and adopted by the Nigerian government in 2018 , does not take into account, for instance, the shortage of land for implementing ranch projects in some states, i.e. does not consider all nuances for the successful implementation of this initiative.

First of all, it is necessary to refine this law with the obligatory participation of farmers, pastoralists, specialists in the development of livestock in fenced areas, and representatives of Nigeria's regions. In addition to identifying areas for fenced cattle breeding, it is necessary to develop a detailed financing arrangement for each planned ranch. It is pertinent for the plan to concentrate financial resources and direct them towards the creation of livestock farms (ranches), pig farms and poultry farms, and their provision with modern technical equipment. In this regard, the modern development strategy of the industry should provide for an exclusively innovative path based on the use of modern equipment and technologies that ensure the mounting production of livestock products. Particular attention should be paid to such elements of innovative development as training in the field of upkeep of various farm animals and the use of modern technologies for their breeding, fattening, and processing.

The development of the livestock sector can not only solve the problem of food security, but also facilitate the diversification of exports. The expansion of agricultural exports, for instance, of by-products such as animal skins, should contribute to the economic growth of the country and the development of international cooperation, as well as become a significant source of foreign exchange. The growth of export activity will determine the development of agricultural specialization, which may result in the redistribution of the country's resources from the extractive sector to agriculture. The expansion of agricultural exports will provide a solution to the problem of population employment, because as production expands new jobs are created. Thanks to the development of agricultural exports, the efficiency of the use of domestic resources of the country should increase and linkages between existing agricultural enterprises should develop. An opportunity should also emerge to establish new enterprises and introduce them into the existing network of organizations.

\section{References}

1. Agriculture, in Nigeria. A Reference Monograph (Moscow: Institute for African Studies, 2013)

2. $\quad$ N.G. Gavrilova, Eurasian Law Journal, 5 (120), 380-384 (2018) 
3. T.S. Denisova, Asia and Africa today, 8, 12-17 (2015)

4. S.V. Kostelyanets, Vostok, 4, 196-202 (2014)

5. International Crisis Group, Report №252/Africa. Herders against Farmers: Nigeria's Expanding Deadly Conflict (2017)

6. International Crisis Group, Report №262/Africa. Stopping Nigeria's Spiralling Farmer-Herder Violence (2018)

7. S.V. Kostelyanets, Paths to Peace and Security, 2, 101-113 (2016)

8. Mercy Corps, The Economic Costs of Conflict: Evidence on Violence, Livelihoods and Resilience in Nigeria's Middle Belt (2015)

9. S.C. Ogala, Advances in Multidisciplinary \& Scientific Research Journal Publication 4, 101-112 (2018)

10. N.G Gavrilova, T.S. Denisova, Asia and Africa today 7, 54-58 (2019)

11. FAOSTAT. Suite of Food Security Indicators. http://www.fao.org/faostat/en/\#data/FS

12. O.O. Ikelegbe, D.A. Edokpa, African Journal of food, agriculture, nutrition and development 13(5), 8388-8400 (2013)

13. The Nigerian Army Farms and Ranches Ltd (NAFARL), https://nafarl.com.ng/about/

14. S.V. Kostelyanets, Asia and Africa today 1, 40-43 (2010) 